\title{
The Evaluation of Substrates and Trichoderma sp. Isolates for Cellulase Production
}

\author{
Eka Triwahyuni $^{1)}$, Yosi Aristiawan $^{1)}$, Novita Ariani ${ }^{1)}$, Haznan Abimanyu ${ }^{1)}$, Trisanti Anindyawati ${ }^{2)}$ \\ 1) Research Center for Chemistry-LIPI Kawasan Puspiptek Serpong, Tangerang 15314, Indonesia \\ 2) Research Center for Biotechnology-LIPI J1. Raya Bogor Km 46 Cibinong 16911, Indonesia \\ *Corresponding author: eka.triwahyuni@lipi.go.id
}

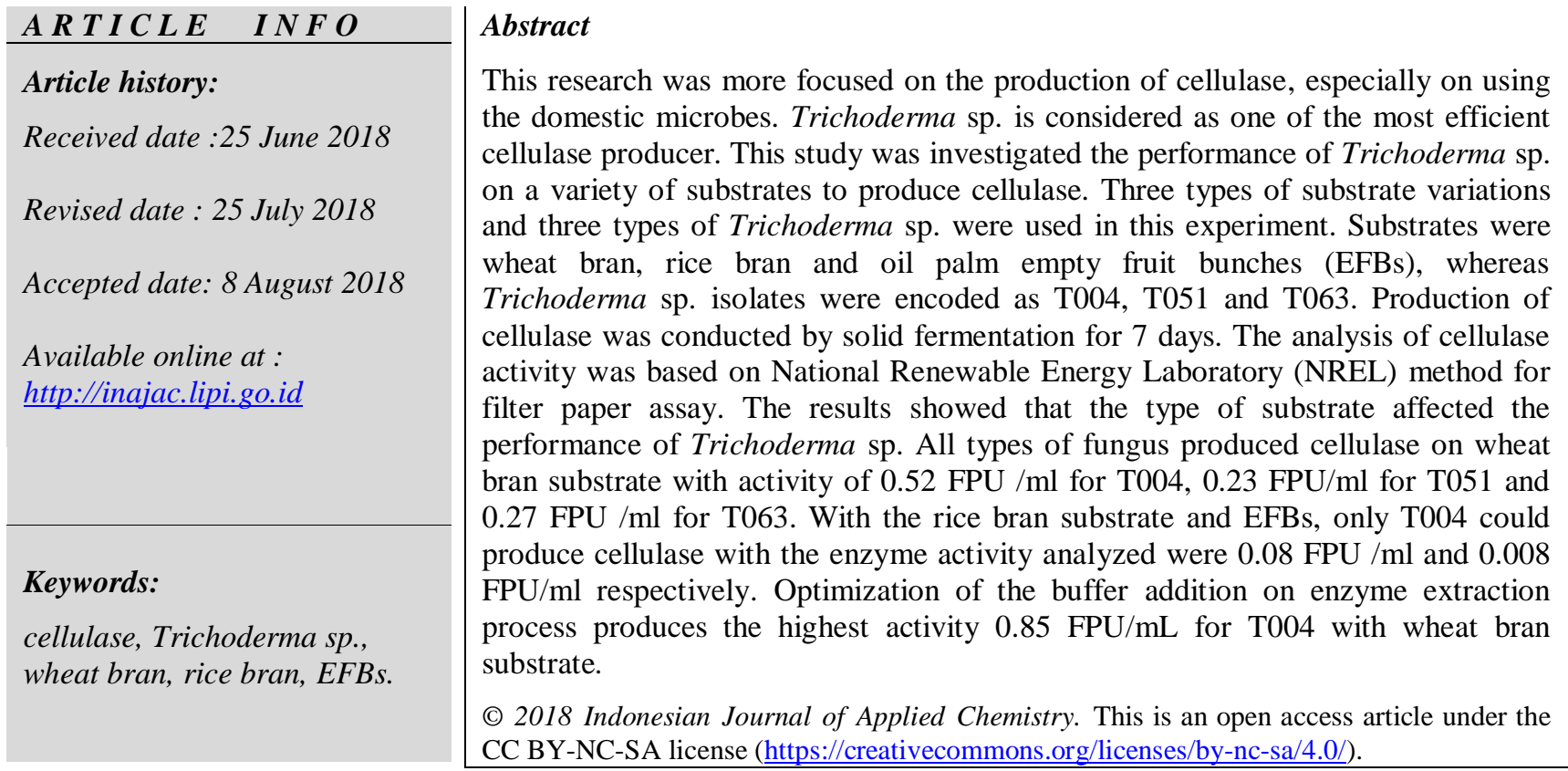

\section{INTRODUCTION}

World energy demand increases every year but production of fossil fuel continues to decrease. It encourages developing alternative energy such as biofuels. Global biofuels production, including bioethanol and biodiesel, remain static in 2012 in absolute volumes at roughly 110 billion liters, caused by high feedstock prices. The cost of biofuel production was $50 \%$ to $80 \%$ of total production costs [1]. Due to the high price of feedstock for first generation biofuels, lignocellulosic biomass was developed for feedstock of biofuels, particularly ethanol. Cellulose and hemicellulose, which represent the largest component of lignocellulose biomass such as straw from corn, cotton, soy and wheat, sugarcane bagasse, bond with lignin in the cell wall matrix that needs to be broken [2]. The potential of cellulose as an alternative raw material has stimulated research of bioconversion processes which hydrolyze cellulose into soluble sugars as feedstock for alcohol fermentations [3].

The hydrolysis process can be performed in different ways, either chemical or enzymatic [4]. Enzymatic hydrolysis gives two advantages of the process: low corrosion problems and low toxicity of the hydrolysates. Lignocellulosic hydrolysis used several enzymes, which the most popular are cellulases [5]. Cellulase is a generic name for the enzymes group which catalyzes the hydrolysis of cellulose and related celluoligosaccharide derivatives [6]. Cellulases are produced by a number of microorganisms. Cellulolytic microbes are primarily carbohydrate degraders and generally unable to use proteins or lipids as energy sources for growth [7]. Most commonly studied 
cellulolytic organisms include fungal species such as Aspergillus, Trichoderma, Humicola, Penicillium, bacteria species such as Pseudomonas, Cellulomonas and actinomycetes species such as Actinomucor and Streptomyces [5].

Three major types of cellulase activities are recognized in the cellulase systems of such fungi: 1) endoglucanases (EG), 2) exoglucanases including glucohydrolases and cellobiohydrolases $(\mathrm{CBH})$ and 3) $\beta$ glucosidases or cellobiases [8]. The function of each component can be seen in Table 1. For growth and product formation, cellulolysis need appropriate conditions. Commercial cellulase preparations from most often used species Trichoderma reesei and $T$. viride are popular as they contains high activities of both exo-glucanase and endo-glucanase but low levels of $\beta$-glucosidase. $T$. reesei produces at least two CBHs, five EGs, and two $\beta$ glucosidases [9]. Assays for determining cellulase activity have been classified differently over years of cellulase research. Different cellulase assays that are classified within two groups: (1) total cellulase activity and (2) individual cellulase activity including endoglucanases, exoglucanases, and $\beta$ glucosidases. Total cellulase activity was measured by filter paper assay (FPA). Endoglucanases, activity was measured by carboxymethyl cellulase, exoglucanases was measured by Avicel, and $\beta$-glucosidases activity was measured by $p$ NPG, cellobiose [10].

The important factors that affecting yield of enzyme production are the type of strain, culture conditions, nature of the substrate and availability of nutrients [11]. Cellulolytic fungi used cellulose as a primary carbon source. Pure, crystalline cellulose, such as Solka Floc, Avicel, and cotton are good cellulose inducers, but they are expensive. It is important to use a less expensive substrate for cost reduction [12]. It has been reported that low cost substrates like wheat flour, wheat bran, rice straws and molasses are suitably effective for growth and enzyme production [13, 14].
Table 1. Components and mode of action of aerobic fungal cellulases.

\begin{tabular}{|c|c|}
\hline Enzyme & Mode of action \\
\hline $\begin{array}{l}\text { Endoglucanase (EG) } \\
\text { (Endo-1,4- } \beta \text {-D-glucan } \\
\text { cellobiohydrolase) } \\
\text { EC 3.2.1.4 }\end{array}$ & Cleaves linkages at random \\
\hline $\begin{array}{l}\text { Cellobiohydrolase }(\mathrm{CBH}) \\
\text { (Exo-1,4- } \beta \text {-D-glucan } \\
\text { cellobiohydrolase) } \\
\text { EC 3.2.1.91 }\end{array}$ & $\begin{array}{l}\text { G-G-G-G-G-G-G-G-G-G-G } \\
\text { Releases cellobiose either } \\
\text { from the reducing or the } \\
\text { non-reducing end }\end{array}$ \\
\hline $\begin{array}{l}\text { Glucohydrolase (Exo-1,4- } \\
\beta \text {-D-glucan glucohydrolase) } \\
\text { EC 3.2.1.74 }\end{array}$ & $\begin{array}{l}\mathrm{G}_{2} \mathrm{G}-\mathrm{G}-\mathrm{G}-\mathrm{G}-\mathrm{G}-\mathrm{G}-\mathrm{G}-\mathrm{G}-\mathrm{G}-\mathrm{G}- \\
\text { Releases glucose from the } \\
\text { non-reducing end }\end{array}$ \\
\hline $\begin{array}{l}\beta \text {-glucosidase or cellobiase } \\
\text { ( } \beta \text {-D-glucoside } \\
\text { glucohydrolase) } \\
\text { EC } 3.2 .1 .21\end{array}$ & $\begin{array}{l}\text { G-G G-G-G } \mathrm{G}^{\mathrm{G}-\mathrm{G}-\mathrm{G}-\mathrm{G}} \\
\text { Releases glucose from } \\
\text { cellobiose and short-chain } \\
\text { glucose oligomers }\end{array}$ \\
\hline
\end{tabular}

Source: Bhat and Hazlewood, 2001.

In this study, the substrates used were wheat bran, rice bran and oil palm empty fruit bunches (EFBs). Wheat bran is produced in large quantities as residue of the milling process which is $14-25 \%$ of the grain $[15,16]$. Rice bran is residue of the rice milling process. The milling of 1-ton rice will produce $60-80$ $\mathrm{kg}$ rice bran [17]. The EFBs is produced as residue of Crude Palm Oil (CPO) production. The dry weight of EFBs is about $8 \%$ of the dry weight of Fresh Fruit Bunches (FFB) [18] or $39 \%$ of the weight of CPO produced [19]. Palm Oil plantations can produce 32 tons of FFB per hectare per year, and 6-7 tons of CPO per hectare per year [20]. Agro-industrial residues which were abundantly available have been thought as potential substrate in cellulase production.

The aim of this work was to investigate the performance of Trichoderma sp. Indonesian isolates in various type of substrates. These substrates were chosen from low cost raw material for the production of cellulase. After the combination of substrates and isolates which produce the highest cellulase activity were obtained, optimization of the buffer addition on enzyme extraction process will be conducted to get a higher cellulase activity. 


\section{EXPERIMENTAL SECTION}

\subsection{Materials and methods}

\subsubsection{Substrates}

Three different agro-industrial residues, wheat bran, rice bran and EFBs were used as substrates for cellulase production. Wheat bran was purchased from PT. Bogasari, rice bran was from local market, and EFBs was taken from an Palm Oil Plantation belongs to PT. Perkebunan Nusantara VIII, in Pandeglang, Banten, Indonesia.

\subsubsection{Microorganisms and Culture Conditions}

Three Indonesian isolates of Trichoderma sp. (T004, T051 and T063) were used for this study. T004 was isolated from District of Liwa in Lampung Province whereas T051 and T063 were isolated from District of Maros in South Sulawesi Province [21]. These isolates were obtained from Biotechnology Culture Collection (BTCC), Research Center for Biotechnology-Indonesian Institute of Sciences (LIPI) and maintained on potato dextrose agar (PDA) slants at $27^{\circ} \mathrm{C}$. Fully sporulated cultures obtained after 7 days were preserved at $4^{\circ} \mathrm{C}$. The cultures on PDA slants were used as inoculum, where cultures were transferred first onto PDA plates and grown for 7 days.

\subsubsection{Preparation of Nutrient Solution}

Nutrient solutions for three kinds of substrates consisted of $2 \mathrm{~g} / \mathrm{L} \mathrm{KH}_{2} \mathrm{PO}_{4}, 0.4 \mathrm{~g} / \mathrm{L}$ $\mathrm{CaCl}_{2} .2 \mathrm{H}_{2} \mathrm{O}, \quad 0.3 \mathrm{~g} / \mathrm{L} \mathrm{MgSO} 4.7 \mathrm{H}_{2} \mathrm{O}, 1.4 \mathrm{~g} / \mathrm{L}$ $\left(\mathrm{NH}_{4}\right)_{2} \mathrm{SO}_{4}$ and $0.3 \mathrm{~g} / \mathrm{L}$ urea. For EFBs, $1 \mathrm{~g} / \mathrm{L}$ glucose was added. These components were diluted in $0.05 \mathrm{M}$ citrate buffer $\mathrm{pH} 4.8$ and stirred [12] with modification

\subsubsection{Preparation of Crude Enzyme}

The crude enzyme was produced by solid fermentation method. Three plugs of each isolate was inoculated on each medium consisted of $10 \mathrm{~g}$ of substrate and $15 \mathrm{~mL}$ of nutrient solution in Erlenmeyer flask and then incubated at $27^{\circ} \mathrm{C}$ for 7 days. The solid fermentation process performed in two replicates for each variation of substrates and Trichoderma isolates. The cellulolytic enzymes were extracted with $25 \mathrm{~mL}$ of $0.5 \mathrm{M}$ citrate buffer $\mathrm{pH} 4.8$, then mixed and preserved at $4^{\circ} \mathrm{C}$. The extract was filtered by using filter cloth. The filtrate was used as a crude enzyme.

2.1.5 Optimization of enzyme activity by the addition of various buffer concentration on extraction process

Preparation of crude enzyme was performed by using substrate conditions and isolate which produced the highest cellulase activity. The cellulolytic enzymes were extracted by using of $0.5 \mathrm{M}$ citrate buffer $\mathrm{pH}$ 4.8 with $15,20,25$ and $30 \mathrm{~mL}$ repectively, then mixed and preserved at $4^{\circ} \mathrm{C}$ for approximately $2 \mathrm{~h}$. The extract was filtered by using filter cloth. The filtrate was considered as crude enzyme. The solid fermentation process performed in two replicates for each variation of buffer.

\subsubsection{Measurement of enzyme activities}

Filter paper activity (FPase) for total cellulase activity in the filtrate was determined according to a measurement of cellulase activities method from National Renewable Energy laboratory (NREL) [22]. The detection of glycosidic bond cleavage by this method involves the parallel and identical treatment of three categories of experimental tubes (assay mixtures, blanks and the appropriately diluted cultured filtrate as enzyme source was added to Whatman no. 1 filter paper strip $(1 \times 6 \mathrm{~cm}$; $50 \mathrm{mg}$ ) immersed in one $\mathrm{mL}$ of $0.05 \mathrm{M}$ citrate buffer of $\mathrm{pH} 4.8$. After incubation at $50^{\circ} \mathrm{C}$ for $60 \mathrm{~min}$, the reducing sugar released was estimated by dinitrosalicylic acid (DNS) method [22]. One unit of filter paper (FPU) activity was defined as the amount of enzyme releasing $2.0 \mathrm{mg}$ of reducing sugar from filter paper per $\mathrm{ml}$ in $60 \mathrm{~min}$. The calculation of FPU activity can be seen in equation 1 .

FP activity $=\frac{0.37}{[\text { enzyme] releasing } 2.0 \mathrm{mg} \text { glucose }} \mathrm{units} / \mathrm{mL}$

\section{RESULTS AND DISCUSSION}

The Trichoderma initially produces a dense pure white mycelium but sometimes mycelial mat on the casing layer gradually turns to a 
green color [23]. The isolated of Trichoderma sp. can be seen in Figure 1. Three types of Trichoderma sp. used have a different colony color. The colony color of T004, T051 and T063 were white, greenish white and dark green, respectively. The growth of three isolates of Trichoderma sp. (T004, T051 and T063) after incubation for 7 days at the three types of substrates showed that mycelium growth increased with pure white color for T004 and T051 and green color for T063. Figure 2. showed an example of the growth of Trichoderma sp. (T004, T051 and T063) on wheat bran substrate.

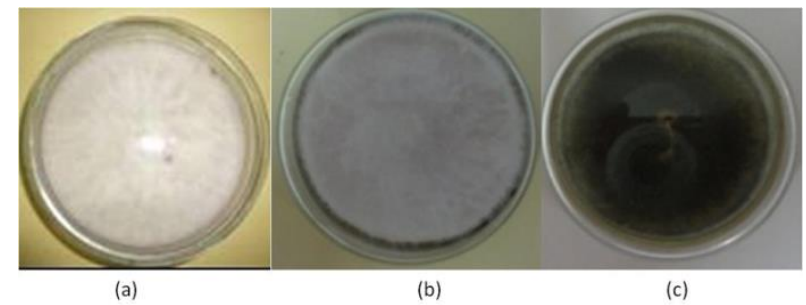

Figure 1. Trichoderma sp. in PDA medium (a) T004, (b) T051, (c) T063.

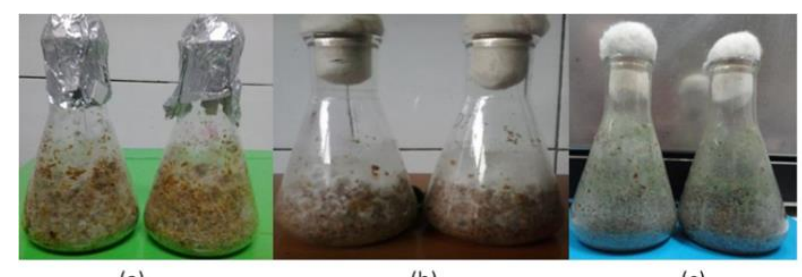

(a)

(b)

(c)

Figure 2. Trichoderma growth on wheat bran after
7 days' incubation time: (a) T004, (b) T051, (c) T063.

The variation of Trichoderma sp. with different substrates for cellulase production resulted a different activity of enzyme. Analysis of cellulase activity used NREL method for Filter paper assay (FPA). The FPA is the key method for analysis of total cellulase activity. To compare the efficacy of cellulase activity between microorganisms or their secreted enzymes, techniques for measuring total cellulase activity are required [10].

In this study, Trichoderma sp. T004 can work and produce cellulase with different activities on three types of substrates wheat bran, rice bran and EFBs which can be seen in Table 2. The Table shown that the highest cellulase activity was obtained on wheat bran substrate at $0.52 \mathrm{FPU} \mathrm{mL}$, whereas the rice bran was $0.08 \mathrm{FPU} / \mathrm{mL}$ and EFBs was 0.008 FPU/mL. On two isolates of Trichoderma sp. (T051 and T063) only produce cellulase on wheat bran substrate, whereas on rice bran and EFBs the activity of cellulase were not detected. The cellulase activity data on T051 and T063 can also be seen in Table 2. The values of cellulase activity are the average data of two replications process of solid fermentation.

Table 2 showed wheat bran give higher activity of enzyme in every isolate of

Table 2. The cellulase activity of Trichoderma sp. T051 and T063 grown on different substrates

\begin{tabular}{lcccc}
\hline \multicolumn{1}{c}{ Media } & Trichoderma sp. & $\begin{array}{c}\text { Cellulase activity } \\
\text { (FPU/mL) }\end{array}$ & $\begin{array}{c}\text { Protein Concentration } \\
(\mathbf{m g} / \mathbf{m l})\end{array}$ & $\begin{array}{c}\text { Specific activity } \\
\text { (U/ mg protein) }\end{array}$ \\
\hline \multirow{3}{*}{ Wheat bran } & T004 & 0.52 & 113.1 & 0.005 \\
& T051 & 0.23 & 85.8 & 0.003 \\
& T063 & 0.27 & 141.9 & 0.000 \\
\hline \multirow{3}{*}{ Rice bran } & T004 & 0.08 & 30.3 & 0.003 \\
& T051 & ND & 46.2 & - \\
\hline \multirow{3}{*}{ EFBs } & T063 & ND & 129.9 & - \\
& T004 & 0.008 & 159.6 & - \\
& T051 & ND & 163.2 & - \\
\hline
\end{tabular}

\footnotetext{
*) $N D=$ not detected

*) Above data showed enzyme activity value with validation measurement method. Precision method is $8.4 \%$ $R S D(n=9)$
} 
Trichoderma sp. than the other substrates. It can be observed that the substrate as carbon source in the medium affects considerably in the production of the cellulolytic enzymes by Trichoderma sp. Wheat bran, rice bran and EFBs invariably affected the synthesis of cellulase in the medium. The carbon sources difference on the three type of substrates characteristics which the sum of cellulose, hemicellulose and starch between these substrates are approximately on same level concentration, about range $70 \%$. EFBs has less carbon source with content of carbons about $50 \%$, only cellulose and hemicelluloses. The significant difference was in lignin content, which is highest on EFBs. The presence of lignin causes difficulties for fungus to access and consume carbon sources. Lignin is the most difficult component of biomass to be degraded due to its complex structure, high molecular weight and high insolubility. Lignin was linked by carbon-carbon and other bonds to form tri-dimensional network associated with the hemicelluloses polysaccharides inside the cell wall [24]. The production of cellulase was induced only in presence of the substrate, and repressed when easily utilizable sugar are available [5]. The more lignin in substrate, the less sugar will be available for production of cellulase. However, wheat bran contained easier utilizable sugar and less lignin than rice bran. The easier access to sugar was suggested the cellulase from wheat bran has highest cellulase activity in all used three types of fungus.

The evaluation of substrates and Trichoderma isolates for cellulase production indicated that the use of wheat bran and T004 isolate produces the highest of enzyme activity $0.52 \mathrm{FPU} / \mathrm{mL}$. Similar result was reported in previous studies. Cellulase production by using wheat bran and Trichoderma koninggii D-64 produce enzyme with activity $0.5 \pm 0.2$ FPU/mL [25], sugar beet pulp and $T$. reesei achieved $0.46 \mathrm{IU} / \mathrm{mL}$ of filter paper activity was obtained [12]. All reported results were based on cellulase activity in crude form of enzyme. Crude enzyme usually has lower activity because there are so many impurities in the liquid. Although this number of activity is low even for crude form of enzyme, this result denoted that the whole process, especially wheat bran and T004, is good enough as a platform for cellulase production feasibility studies. Developments to get the higher activity of cellulase were obviously attractive.

The next step to get the higher enzyme activity from wheat bran substrate and T004 was by improving the extraction optimum condition such as the amount of buffer addition on extraction process. In the cellulase production by solid state fermentation, extra buffer for enzyme extraction was needed. In the first method, the buffer addition was 25 $\mathrm{mL}$, then a variation of buffer used i.e. 15,20 and $30 \mathrm{~mL}$. The cellulase activities on various buffer addition can be seen in Table 3 .

Table 3. The cellulase activity of Trichoderma $s p$. T004.

\begin{tabular}{lcc}
\hline \multicolumn{1}{c}{ Substrate } & $\begin{array}{c}\text { Buffer } \\
\text { addition } \\
\text { (mL) }\end{array}$ & $\begin{array}{c}\text { Cellulase } \\
\text { activity } \\
\text { (FPU/mL) }\end{array}$ \\
\hline & 15 & 0.85 \\
10g of wheat & 20 & 0.31 \\
bran, 15 mL of & 25 & 0.52 \\
nutrient solution & 30 & 0.33 \\
\hline
\end{tabular}

Table 3. shows that the addition of buffer affected cellulase activity. Several previous studies using a variety of solution for enzyme extraction. Cellulase production from $5 \mathrm{~g}$ of corn and $10 \mathrm{~mL}$ of distilled water using 100 $\mathrm{mL}$ distilled water or $100 \mathrm{~mL} \mathrm{pH}$ solutions for extraction [26]. Cellulase from $20 \mathrm{~g}$ of wheat bran and $20 \mathrm{~mL}$ of distilled water using $5 \mathrm{~mL}$ of distilled water for extraction [21]. Extraction cellulase from Aspergillus oryzae using $100 \mathrm{~mL} 0.2 \mathrm{M}$ sodium acetate buffer, $\mathrm{pH}$ 5.2 to extract $1 \mathrm{~g}$ of solid (myceliamat) [27]. Based on the differences in the solutions addition on the enzyme extraction, in this study conducted an additional variation of the buffer volume on enzyme extraction to determine its effect on cellulose activity. The highest activity was obtained at $15 \mathrm{~mL}$ of buffer addition that is $0.85 \mathrm{FPU} / \mathrm{mL}$. The main step for the next study was purification system. 
Purification by using salt saturation, dialysis, ion exchange and gel filtration chromatography was relied to obtain high activity of cellulase. In average of this process increased total cellulase activity at about 50 times crude enzyme activity.

\section{CONCLUSION}

The present work showed that low cost substrate can be used as carbon source to produce cellulase. Wheat bran seems more suitable than rice bran and EFBs as substrate for cellulase production by three strains of Indonesian Trichoderma sp. indicating the highest activity in T004 isolate. The highest cellulase activity was $0.85 \mathrm{FPU} / \mathrm{mL}$ by using T004 and wheat bran at $15 \mathrm{~mL}$ buffer addition on enzyme extraction. This matter can be view based on the composition of substrate where wheat bran has many carbon sources and less blockage from lignin.

\section{ACKNOWLEDGEMENT}

This work was funded by National Priority Project of fiscal year 2013.

\section{REFERENCES}

[1]. International Energy Agency. Tracking Clean Energy Progress 2013. IEA Input to the Clean Energy Ministerial.

[2]. Colombatto, D., Mould, F.L. and Bhat, M.K. Use of fibrolytic enzymes to improve the nutritive value of ruminant diets. A biochemical and in vitro rumen degra-dation assessment. Animal Feed Science and Technology, 107, 201-209. doi:10.1016/S0377-8401(03)00126-3. (2003).

[3]. Coughlan, M.P. Cellulose degradation by fungi, 1-36. in WM Fogarty, CT Kelly (ed.), Microbial Enzymes and Biotechnology, 2nd ed. Elsevier Applied Science, London, United Kingdom. (1990).

[4]. Galbe, M., and Zacchi, G. A review of the production of bioethanol from softwood. Appl. Microbiol. Biotechnol. 59(6), 618-628. (2002).

[5]. Sukumaran, R.K, Singhania, R.R. and Pandey, A. Microbial cellulasesproduction, applications and challenges. Journal of Scientific \& Industrial Research, Vol. 64, 832-844. (2005).

[6]. Shallom, D. and Shoham, Y. Microbial hemicelulases. Current Opinion in Microbiology, Vol. 6, 219-228. doi:10.1016/S1369-5274(03)00056-0. (2003).

[7]. Lynd L. R, Weimer P.J, van Zyl W H and Pretorius I S,. Microbial cellulase utilization: fundamentals and biotechnology, Microbiol Mol. Biol. Rev., Vol. 66, 506-577. (2002).

[8]. Bhat M.K., Hazlewood G.P. Enzymology and other characteristics of cellulases and xylanases in Bedford MR, Partridge GG (eds) Enzymes in farm animal nutrition. Wallingford: CABI Publishing; p. 11-60. (2001).

[9]. Leite, R.S.R., Alves-Prado, H.F., Cabral, H., Pagnocca, F.C., Gomes, E., Da-Silva, R. Production and characteristics comparison of crude $\beta$-glucosidases produced by micro-organisms Thermoascus aurantiacus and Aureobasidium pullulans in agriculture wastes. Enzyme and Microbial Technology Vol. 43(6), 391-395. (2008).

[10]. Dashtban, M., Maki, M., Leung, K.T., Mao, C., Qin, W. Cellulase activities in biomass conversion: measurement methods and comparison. Critical Reviews in Biotechnology, 1-8. (2010).

[11]. Pandey, A., Soccol, C., Rodriguez Leon, J., Nigam, P.,. "Solid State Fermentation in Biotechnology Fundamentals and Applications", Asiatech Publ. Inc., New Delhi, p.50-225. (2001).

[12]. M. Moosavi-Nasab, M. Majdi-Nasab. Cellulase production by Trichoderma reesei using sugar beet pulp. Iran Agricultural Research, Vol. 25(2) and Vol. 26(1-2). (2007).

[13]. Mehta, V.J., Thumar, J.T. and Singh, S.P. Production of alkaline protease from an alkaliphilic actinomycete. Bioresource Technology, Vol. 97, 1650- 
1654.

doi:10.1016/j.biortech.2005.07.023.(200 6).

[14]. Sen, S., Veeranki, V.D. and Mandal, B. 2009. Effect of physical parameters, carbon and nitrogen sources on the production of alkaline protease from a newly isolated Bacillus pseudofirmus SVB1. Annals of Microbiology, Vol. 59, 531-538. doi:10.1007/BF03175142.

[15]. Nandini C.D, Salimath P.V. Carbohydrate Composition of Wheat, Wheat Bran, Sorghum and Bajra With Good Chapati/roti (Indian Flat Bread) Making Quality. Food Chem, Vol. 73, 197-203. (2001).

[16]. Neves M.A, Shimizu N., Kimuri T., Shiiba K. Wheat milling by-products fermentation: potential substrate for bioethanol production. Life Sci J. Vol. 3(2), 83-87. (2006).

[17]. Kailaku, S.I., Budiyanto, A., and Hadipernata, M. Antioksidan oryzanol from rice bran. Balai Besar Penelitian dan Pengembangan Pascapanen Pertanian. Apresiasi Hasil Penelitian Padi, 849-857. (2007).

[18]. Sheil, D., A. Casson, E. Meijaard, M. van Noordwijk, J. Gaskell, J.S. Groves, K. Wertz, M. Kanninen. The impacts and opportunities of oil palm in Southeast Asia, CIFOR, Bogor, Indonesia.(2009).

[19]. Yano, S., K. Murakami, S. Sawayama, K. Imou, S. Yokoyama. Bioethanol production potential from oil palm empty fruit bunches in southeast asian countries considering xylose utilization, Journal of the Japan Institute of Energy, 88(10), 923-926. (2009).

[20]. Sudiyani, Y., Styarini, D., Triwahyuni, E., Sudiyarmanto, Sembiring, K.C., Aristiawan, Y., Abimanyu, H., Han, M.H. 2013. Utilization of biomass waste empty fruit bunch fiber of palm oil for bioethanol production using pilot-scale unit. Energy Procedia Vol. 32, 31-38.

[21]. Fahrurrozi, Ratnakomala, S., Anindyawati, T., Lisdiyanti, P., Sukara, E. Rapid assessment of diverse
Trichodermal isolates of Indonesian origin for cellulase production. Annales Bogorienses Vol. 14(1), 39-44. (2010).

[22]. Adney, B., Baker, J. Measurement of cellulase activities. Laboratory Analytical Procedure (LAP). Technical Report NREL/TP-510-42628. (2008).

[23]. Choi, I.Y, Joung, G.T, Ryu, J., Choi, J.S and Choi, Y.G.. Physiological characteristics of green mold (Trichoderma spp.) isolated from oyster mushroom (Pleurotus spp.). Mycobiology 31(3), 139-144. (2003).

[24]. Ibrahim, M.N.M., Rosli, W.D.W., Chuah, S.B. Monitoring quality of soda black liquor of oil palm empty fruit bunch fibers in terms of storage time and temperature. Journal of Technology 42 (C), 21-28. (2005).

[25]. Wang, Z., Ong, H.X., Geng, A. cellulase production and oil palm empty fruit bunch saccharification by a new isolate of Trichoderma koningii D-64. Process Biochemistry Vol. 47,1564-1571. (2012).

[26]. Amir, I., Zahid, A., Yusuf, Z., Iqbal, H., Aish, M. Irshad, M., Sajid, M. Optimization of cellulase enzyme production from corn cobs using Alternaria alternata by solid state fermentation. Journal of Cell and Molecular Biology 9(2), 51-56. (2011).

[27]. Begum, M.F., Absar, N. Purification and characterization of intracellular cellulase from Aspergillus oryzae ITCC-4857.01. Mycobiology 37(2), 121-127. (2009). 